\title{
Return of a Subject in the German Metafiction of 1960-1990
}

\author{
Vera V. Kotelevskaya* \\ Southern Federal University \\ 105/42 Bolshaia Sadovaia Str., Rostov-on-Don, \\ 344006, Russia
}

Received 10.01.2017, received in revised form 02.03.2018, accepted 12.03.2018

The article examines a so-called "death of a subject" based on the German metafiction of 1960-1990. This subgenre is interpreted as the most adequate literary form of problematization of the modern subject. The protagonist of metafiction is most often an artist or an intellectual. The narrative is superseded by self-reflection of the writing subject. Self-consciousness of the main character is the centre of the author's attention, therefore a meta-novel often takes the form of a self-reflective narrativea diary, notes, a stream of consciousness. The article analyses the creative work of Thomas Bernhard and especially has an increased focus on his novel "Correction" (1975). Such properties of a metanovel as the ambivalence of "self" and the Other, the problematization of writing, the interpretation of art as life and life as art are analysed based on the example of the novel "Correction". It is proved that German metafiction keeps its connection with modernism and does not lose the semantic "depth", catharsis, as well as the romantic idea of an artist as a "genius".

Keywords: modernist literature, postmodern, post-structuralism, death of subject, death of author, German literature, metafiction, Thomas Bernhard.

DOI: 10.17516/1997-1370-0292.

Research area: philology.

\section{Introduction into the problem}

Comprehension of the subject's problem as the central construct of modernity in the German cultural and historical context of the second half of the $20^{\text {th }}$ century is closely connected with the "after Auschwitz" situation (Adorno, 1998: 30). Despite the "left" turn of the 1960's, the problems of "post-war" literature (Nachkriegsliteratur) are preserved here, regardless of whether the traumatic experience is represented or superseded. Perhaps, this is one of the decisive reasons why, in the countries of the German language, the grand récits crisis (Lyotard) was perceived without wit and gaiety typical of the Romanesque culture and without proper interest in the ironic-fictional deconstruction of literary forms in the spirit of Raymond Queneau's "Exercises in style" or John Barth's "Lost in the Funhouse". Schiller's idea that "life is serious, art is joyful" was radically edited by Theodor Adorno who stated that "it is no longer possible to imagine any joyful art" (Adorno, 1974: 153). And

(C) Siberian Federal University. All rights reserved

* Corresponding author E-mail address: vvkotelevskaya@sfedu.ru 
although West German and Austrian literature of the 1950's-1970's also had their own avantgarde - for example, the Vienna Group, the Graz Group, Joseph Beuys, Ernst Jandl, the young and provocative Peter Handke - here, the tendencies of realism and modernism with their "exaltation of an individual", as well as an "ordeal" and a "search for Self" remained strong enough (Schlinkert, 2011). "Disappearance of an affect" as one of the defining features of postmodern art and literature obviously did not turn into "decorative gaiety" and "deliberate frivolity" in the works of German-speaking authors (Jameson, 1997: 55).

Nevertheless, the discussion about a subject (a subject of cognition, experience, creativity, writing) that was initiated in Europe in the 1960's by French poststructuralists changed the literary and artistic situation in the German-speaking countries ${ }^{1}$.

The purpose of this article is to examine the features of the "death of a subject" project on the basis of a German-speaking metafiction of the 1960's-1990's. The subject of the analysis is the novel written by Thomas Bernhard, the object of "close reading" is his novel "Correction" (1975).

This kind of novel genre turned out to be the most adequate literary form for the problematization of the subject. An "artist" (writer, poet, musician, painter, etc.) or an intellectual most often becomes the main character of a meta-novel. The narrative is almost completely superseded by reflection on the subject of writing and the novel form, on language and art itself. Self-consciousness of the poetic "self" is placed in the centre of the author's attention, therefore a meta-novel often has a form of self-reflective narrative - a diary, notes, a stream of consciousness, and in a number of works (for example, Bernhard, Handke, Jelinek, Jirgl) fuses with the form of monodrama. The article will consider some works, in which a reflecting subject is portrayed through a plot of collision or death, since it is in such works where "longing for oneself" (Rilke, 1982: 24), as well as a utopian nature of restoration of the integrity and autonomy of the subject of modernity are discovered. It is this ambivalent situation of the subject's return that is portrayed in the metanovels written by Bernhard, Bachmann, Handke, Frisch, Hilbig, Jirgl, Jelinek.

\section{Topic research status}

Foucault's refusal from an autonomous transcendent subject was mainly directed to the deconstruction of the Cartesian thinking "self", as well as to the exposure of presumption of the rationality of the subject. In the conditions of "after-Auschwitz", on the one hand, and the beginning of the "brave new world", the consumer "society of entertainment", a question of conditions for constructing a subject - anonymous discursive practices, language system, episteme, etc. - turned out be extremely relevant. While Foucault plays the role of a denouncer of the constructiveness of a subject, Roland Barthes, with his idea that a scripter writes under orders of language, has problematized both a romantic myth about genius and a reduced understanding of the author solely as a biographical "self" of a writer.

Some German critics of post-structuralism identify the logic of late capitalism, with its deconstruction of a subject, with the anonymization of art/an artist: "Poststructuralism reproduces (but mostly only at the level of aesthetics and theory) what capitalism, as a system of materialized commodity-money relations, persistently tries to reproduce in everyday life: destruction of subjectivity" (Huyssen, 1997: 38).

A concept of "death of an author" somehow nullified the state of a novel as the leading genre of Western literature, having radically 
problematized a relationship between a subject of writing, a text created by him and a reader.

In the end, the works varying different methods of "the order of discourse" (M. Foucault) (early Peter Handke, A. Robbe-Grillet, I. Calvino, R. Queneau, U. Eco, M. Pavić, J. Barthes, J. Barnes) turned out to be in line. A typical example is "Exercises in style" by R. Queneau (1943/1973), an experimental work identified by the author as an "essay". There, the author reduces himself to a "function" that organizes a hundred discourses demonstrating how various pictures of reality and different subjects are constructed depending on a chosen genre and style. Such texts perfectly demonstrate the Foucault's author-subject construction (Foucault, [199] 1996: 8-42), while the avant-garde literary practice anticipates the theory (undoubtedly, the practice of the Dadaists and Surrealists was the first radical step towards the reduction of the traditional author's self).

The works that continue the modernist tradition of a "novel of self-consciousness" (A.M. Piatigorskii) or a "meta-novel" (M. SchmitzEmans), "metafiction", a "self-conscious novel" (P. Waugh) are in another line. This group includes the novels of the above-mentioned German-speaking authors of the late 1960's and 1990's. Both groups, however, represent a type of prosaic texts that can be attributed to a subgenre of a "autoreflexive postmimetic novel" (Bode, 2005: 322).

The plots of meta-novels narrate "about reading, writing, printing, publishing, translating and destroying books", while a text "reflects on the production and reception of novels from the standpoints of participants in the communication process, and the fragments of the novel themselves act as various novel subgenres and demonstrate characteristic novel strategies" (Schmitz-Emans, 2008: 137-138). In a metanovel, the subject of writing is repeatedly tested for self-identity. Reflecting on the "novel of self- consciousness", the source of which goes back to Rousseau, A.M. Piatigorskii actualizes a focus of the genre on a plot of writing: "Human $<\ldots>$ suffering is resolved in the plot of the novel of self-consciousness as writing (or non-writing) of the novel of self-consciousness ("let's write, you and I" or "if you don't write, I'll write it", or even "I write, because you won't write"). According to Merab Mamardashvili's very subtle remark, this is what happens with Monsieur Swann of Marcel Proust. Here, the complete impossibility for the author, Marcel Proust, to simply live was objectified in the impossibility for his hero Swann to write a novel when living" (Piatigorskii, 1996: 268).

It should be emphasized that the problematization of "self" as a writer in a German-speaking metafiction of 1960-1990 correlates mostly to the modernist tradition of criticizing the language (Nietzsche, Mallarmé, Valéry, Hofmannsthal, Wittgenstein, Kraus, Mauthner) and is quite rarely directly related to the influence of the ideas of French poststructuralism or American postmodernism.

A kind of correction of a radical thesis about the "death of an author" is made by the German theorist of art and literature Manfred Frank. In a book "Expressible and inexpressible" (Das Sagbare und das Unsagbare) clearly containing an allusion to Wittgenstein's "Tractatus" in the title, as well as to the early Romantic selfreflection on the language, he tries to reconcile poststructuralism and hermeneutics. M. Frank prefers not to speak about "death" of a subject, but about the subject making cracks in the "wall of language" that breaks through these intervals in the "grill of language" loosening it and widening the hollow spaces between the rods. These "gaps" (Zwischenräume) open the space for reflection, for the subject's freedom from the power of discourses allowing it to assert itself and express itself in an authentic form (Frank, 1980). 
In the monograph "Writing and Absence" (1995) M. Schmitz-Emans also chooses a moderate position, more neo-modernist than postmodernist one, when she speaks about the "abolition", "elimination" of an author. In her opinion, it is necessary to interpret the "author" not as "dead", but as "disappeared", as an "absent" instance that is crossed out by visible signs but nevertheless can be guessed through this crossing. According to the researcher, literature becomes rewriting of the non-readable by describing those boundaries that separate this "unreadable" from "readable" (Schmitz-Emans, 1995: 449).

Thus, a romantic topic of the "inexpressible" returns to the philosophy of literature and literature itself, the metaphors of "cipher", "life-islike-a-book" (Bayer-Schur, 2011) are resurrected, the semantics of uncertainty is actualized.

Concentration on the conditions of writing, reading/self-reading is expressed in the following formal elements of metafiction: a plot about an artist, a plot about creation of a work of art, a novel or a manuscript in general, reflection on the possibility/impossibility to create. However, the artist has already been deprived of early romantic optimism regarding its integrity, creative power and suitability of language for the expression of truth in general. He laments the "untranslatability of the world" and doubts "the capability of literature in general" (SchmitzEmans, 1995: 427). That is why in the meta-novel of 1960-1990 most often depict an apophatic version of the artist's self-affirmation. As a rule, these are stories about creative failure of an artist, about an "artist without a work" (Pontzen, 2000) or, according to Thomas Bernhard's apt words, about a work destroying, "annihilating, erasing" (ausgelöscht) the creator's life (Bernhard, 1986). In the German-speaking cultural space, these plots are partly attributed to the direction of the "new subjectivity" of the 1970's, but the chronological frameworks for implementing this type of a plot is much broader - they cover a period from 1960 to our days, and its origin goes back to romanticism. Let us consider two typical examples of this paradigm of a meta-novel.

\section{Thomas Bernhard:} writing "corrected to death"

Metafiction of Thomas Bernhard (19311989), an Austrian modernist, is composed in the conditions of "death of a subject", under the pressure of the "so-called" (des sogenanten) this is how the writer designates the anonymous power of discourses, their "order" in his works (Foucault, 1970, 1996). However, Bernhard turns his linguistic scepticism towards Nietzsche, Wittgenstein and Kraus. In the post-Nietzschean world, the truth, in search of which romantic philosophy and aesthetics put hopes upon a poetic language, is only "a movable host of metaphors, metonymies, and anthropomorphisms: in short, a sum of human relations which have been poetically and rhetorically intensified, transferred, and embellished, and which, after long usage, seem to a people to be fixed, canonical, and binding. Truths are illusions which we have forgotten are illusions" (Nietzsche, 1979: 84). "The language has to do with the true (das Wahre), the essence of things as little as rhetoric; it does not want to teach, but to transfer subjective excitement and perception to the Other" (Nietzsche, 2015: 426-430).

Bernhard had learned Nietzschean lessons of scepticism perfectly well. His intellectual characters dedicate their lives to a hopeless cause of finding the "truth" in language illustrating by their failure not so much the epistemological incapacity of writing as the impossibility to renounce it, to be implemented differently than in writing or speech. Like the "unnamed" of Beckett, the protagonists of Bernhard's novels realize that apart from "words" "there's nothing else", which means "you must go on $<\ldots>$ you must go on $<\ldots>$ you must say words", and most 
importantly "I will continue" (Beckett: 407408) (italics mine - V.K.). The writing project is implemented by a person, "Self", it is always "my" writing or "my" speech, therefore, in Bernhard's novels a dominant form of unfolding the plot of the writing character is a monologue direct, and most often indirect or improperly experienced speech. In this case, as a rule, the modality of speech is judicial-rhetorical: the protagonist blames and defends simultaneously.

Motives of guilt and self-blame that are archetypal for Austrian and German modernism (Kafka, Jahnn, Mann, Broch, Bachmann, Handke) permeate Bernhard's prose, whether it is about his autofictional pentology or about novels with the Other character. Thus, in the story "A Child" (Ein Kind, 1982), a situation of self-blame is reconstructed all the way to the childhood of an autobiographical hero: the traumatic experience of a failed unauthorized bicycle ride is the starting point. "Ich rechnete, während ich mein Fahrrad durch das Inferno schob, immer wieder alles von oben bis unten durch, addierte, dividierte, subtrahierte, der Urteilsspruch musste entsetzlich sein. $<\ldots>$ Der Gedanke an mich erfüllte mich mit Abscheu. <...> Eigentlich wollte ich auf der Stelle tot sein" (Bernhard, 2011: 466-467).

The casuistry of the "process" over oneself is a peculiar, undoubtedly traumatic embodiment of the author's self-objectification in a hero, a form of detachment from the "inner person" (Bakhtin, 1979) necessary for a self-reflective novel, and transformation of "self" into the Other. Bernhard's meta-novels seem to describe the state of a person watching his own funeral. The "murder" of a hero, his completion that, according to Bakhtin, is necessary for the artistic self-objectification of "self" in the form of the Other, is realized in Bernhard's obituary plots novels dedicated to a deceased friend, in regard of whom an anonymous narrator plays the role of an executor.
"Memory begins to act as a collecting and complete force from the very first appearance of the hero, he is born in this memory (of death), the process of design is a process of commemoration. The aesthetic embodiment of the inner person anticipates the hero's semantic hopelessness from the very beginning. The artistic vision gives us the whole hero estimated and measured to the end" (Bakhtin, 1979: 115). A situation of "commemoration", the artistic completion of the hero and alienation from him prepared by Bakhtin, seems to have been fairly transparently implemented in a number of Bernhard's novels - "The Lime Works" (Das Kalkwerk, 1970), "Walking" (Gehen, 1971), "Correction" (Korrektur, 1975), "The Loser" (Der Untergeher, 1983), etc. Each time it is about a hero working on a manuscript and/or devoting his life to a certain artistic project doomed to failure. At this, unlike most "classical" postmodern meta-novels (metafiction), where the reflection undermines the construction of texts and focuses primarily on the relationship of language, discourses (style, genre, social) and a text (Waugh, [1984] 2013: 565), Bernhard's attention is focused on the modernist problem of "consciousness" and language, on the problem of the embodiment of "self" in a novel and awareness of boundaries of this embodiment.

"Modernist solipsism" (Waugh, [1984] 2013: 582) is fairly consistently expressed in the role structure, plot and stylistics of the novel "Correction" (1975). A plot of creation of the manuscript typical of a meta-novel is realized in a story about Roithamer. The protagonist of the novel devotes his life to two artistic and intellectual projects - "notes about Altensam and everything connected with it", as well as to the idea and embodiment of the architectural idea of the cone-house that stretches up apace with pines in the thick of the forest. The architectural project is designated in the novel as "the product of lifeas-art" (Kunstlebenswerk), and a poor storyline 
of Roithamer illustrates a typically modernist concept of autonomous art: art utopically dominates life essentially delimiting a narrow space of memory-writing (notes about Altensam) and a cone-house to the existential "project" of the artistic "self".

The alienation of the author from the Other from the writing character (Roithamer) is carried out in double distancing: Roithamer composes notes, the text of which is naturally, in the form of experienced speech, woven into the discourse of an anonymous narrator, his friend. The figure of the narrator embodies Bernhard's characteristic device of the ambivalent similarity/difference between the narrator and the character who are in a relationship of friendship - enmity, equation separation. On the one hand, the whole novel is focused exclusively on the reconstruction of the image of Roithamer (the dead one at the time of the narrative: he hangs himself in the forest where he built a cone-house), and in this respect the text perfectly performs the role of an "obituary". The narrator constantly emphasizes the almost twin nature of their relationship (the formula "I am like him"). On the other hand, the narrator formally labels his own and "foreign" speech attributing the authorship to Roithamer (wie er schreibt; er schreibt; so Roithamer; wie aus seinen Aufzeichnungen hervorgeht, etc.), and implicates the motif of horror towards the charisma of a friend's personality, the fear of being absorbed and destroyed by the power of his tragic existentialartistic project (the formula "I am not him").

The collapse of the Roithamer project is described as the gradual destruction of the manuscript of notes that left hundreds of scattered fragments that were depleted, crossed out by his hand. He bequeaths these fragments to the friend to "put them in order" (ordnen), however, as he immerses himself in the text of fragments, he realizes that it is an impossible task. The impossibility to tell a coherent story, the impossibility to reliably reconstruct his life (after all, Roithamer did not manage to finish notes on his homeland and childhood, having almost destroyed them in the course of endless deletions and rewriting, "correcting to death": zu Tode korrigiert) (Bernhard, 1988: 76) quite logically reflects Bakhtin's idea of the impossibility of the biography of "self": "not yet" of a life, its total openness lends itself to narrativization only in the project of the "already completed" art (Bakhtin, 1979: 107). This project is carried out by Bernhard portraying the life of Roithamer from the inside as unfinished, and from the outside - through the narrator's speech - as being completed in the act of narration.

It is common practice to consider Bernhard's protagonists "self-destructors" (Katzschmann, 2003). Indeed, most of his stories introduce the reader to a dead character: his story is reconstructed in hindsight, usually with the help of an incoherent text (manuscript) that is not accurately conveyed by an "eyewitness" (or eyewitnesses like in "The Lime Works"), as well as with the help of retelling his speeches. However, the catastrophe of one project is compensated by the success of another: a story about an artist, who has completely devoted himself to art and suffered a wreck in it, becomes whole (Bakhtin) and is brought to aesthetic completion-perfection by a narrator and author. Thus, language and consciousness, "self" and the novel reveal their unsolvable ambivalence, and sacrifice the full power of the purifying catharsis. And in this respect, Bernhard's metafiction quite clearly demonstrates the unfinished history of Romanticism, which exposed all the helplessness, "misfortune" (Hegel) of an autonomous subject in the collisions of "genius" and life.

\section{Conclusion}

Thus, the German-language literature of the late 1960's-1990's developing under the 
conditions of a Western European discussion about a subject demonstrates the preserved "yearning for oneself" (Rilke), the need to understand the atomic, "schizophrenic" (Jameson, 1997) existence of a modern person in a "gap" between their multiple "self". This is evidenced by the prose of Ingeborg Bachmann, Peter Handke, Günter Grass, Botho Strauss, Wolfgang Hilbig, Reinhard Jirgl and others. The ethical choice, the question of the authenticity of existence remains unanswered. In her famous "Frankfurt Lectures" (1959/1960) I. Bachmann, arguing about the "writing Self", shows that the novel is still developing under the influence of the romantic concept of "cipher", "riddle", the semantic depth, the multidimensionality of which each new author and reader is trying to unravel (Bachmann, 1993: 233). "Self" in a novel, this "Nothing" having no "clear value and scale", existing without any "protection" (Bachmann, 1993: 218), claims itself precisely because of the "loss" of certainty, security (Bachmann, 1993: 230). In the tense space between "self-alienation" (Selbstentfremdung) and "self-acquisition" (Selbsterfindung) (Hagenbüchle, 1998: 7), a short story of the modern subject unfolds, which finds an adequate form of aesthetic self-reflection in the genre of metafiction.

We do not specifically consider literature of the GDR of this period, since up to the end of the 1980's it had been developed in isolation from the all-European cultural context.

\section{References}

Adorno, Theodor W. (1974). Ist die Kunst heiter? (1967) In: Adorno, Theodor W. (1974). Gesammelte Schriften in 20 Bänden. Band 11. Noten zur Literatur. Frankfurt a. M.: Suhrkamp.

Adorno, Theodor W. (1998). Prismen. Kulturkritik und Gesellschaft (1951). In: Adorno Theodor W. Kulturkritik und Gesellschaft I. Gesammelte Schriften in 20 Bänden. Band 10.1. Hg. von Rolf Tiedemann. Darmstadt: Wissenschaftliche Buchgesellschaft.

Bachmann, I. (1993). Das Schreibende Ich. In: Bachmann, I. (1993). Essays. Reden. Vermischte Schriften. München, Zürich: Piper. S. 217-237.

Bakhtin, M.M. (1979). Avtor i geroi v esteticheskoi deiatel'nosti [The author and the hero in the aesthetic activity]. In Estetika slovesnogo tvorchestva [Aesthetics of verbal creativity]. Moscow, 7-180.

Bayer-Schur, B. (2011). Das Buch im Buch. Untersuchungen zu einem Motiv in der gegenwärtigen literarischen Kommunikation. Diss. Göttingen.

Beckett, S. Three Novels: Malone, Malone Dies, The Unnamable. Grove/Atlantic Inc. (Kindle Edition).

Bernhard, Th. (2011). Die Autobiographie: Die Ursache. Der Keller. Der Atem. Die Kälte. Ein Kind. St. Pölten - Salzburg: Residenz Verlag.

Bernhard, Th. (1986). Auslöschung. Ein Zerfall. Frankfurt a.M.: Suhrkamp.

Bernhard, Th. (1988). Korrektur. Frankfurt a. M.: Suhrkamp.

Bode, Ch. (2005). Der Roman. Eine Einführung. Tübingen/Basel: A. Francke.

Foucault, M. (1996). Po tu storonu znaniia, vlasti i seksual'nosti [On the other side of knowledge, power and sexuality]. Works of different years. Translated from French. Moscow, Kastal, 448 p.

Frank, M. (1980). Das Sagbare und das Unsagbare: Studien zur neuesten franzosischen Texttheorie. Frankfurt a. M.: Suhrkamp.

Hagenbüchle, R. (1998). Geschichte und Vorgeschichte der modernen Subjektivität. Berlin, New York: de Gruyter. S. 7-74. 
Huyssen, A., Scherpe, Klaus R. (Hg.). (1997). Postmoderne. Zeichen eines kulturellen Wandels. Hamburg: Rowohlt Taschenbuch Verlag.

Jameson, F. (1997). Postmoderne - Zur Logik der Kultur im Spätkapitalismus. In: Huyssen, A., Scherpe, Klaus R. (Hg.). Postmoderne. Zeichen eines kulturellen Wandels. Hamburg: Rowohlt Taschenbuch Verlag. S. 45-102.

Katzschmann, Ch. (2003). Selbstzerstörer. Suizidale Prozesse im Werl Thomas Bernhards. Köln, Weimar, Wien: Böhlau.

Nietzsche F. (1979). Philosophy and Truth. Selection from Nietzsche's Notebooks of the Early 1870's. Eds, and transl. by D. Breazeale. New Jearsey \& London: Prometheus Books.

Nietzsche, F. (2015). Über Wahrheit und Lüge im außermoralischen Sinn. Stuttgart: Philipp Reclam. Kindle Edition.

Piatigorskii, A.M. (1996). "Drugoi" i "svoe" kak poniatiia literaturnoi filosofii ["Another" and "my own" as concepts of literary philosophy]. In Iazyki russkoi kultury [Languages of Russian culture], Collected works. Moscow, 264-272.

Pontzen, A. (2000). Künstler ohne Werk: Modelle negativer Produktionsästhetik in der Künstlerliteratur von Wackenroder bis Heiner Müller. Berlin: Erich Schmidt Verlag.

Rilke, R.M. (1982). Das Florenzer Tagebuch. Frankfurt a. M.: Suhkamp.

Schlinkert, Norbert W. (2011). Das sich selbst erhellende Bewußtsein als poetisches Ich. Von Adam Bernd zu Karl Philipp Moritz, von Jean Paul zu Sören Kierkegaard. Eine hermeneutischphänomenologische Untersuchung. Hannover: Wehrhahn.

Schmitz-Emans, M. (1995). Schrift und Abwesenheit: historische Paradigmen zu einer Poetik der Entzifferung und des Schreibens. München: Fink Verlag.

Waugh, P. (2013). Metafiction. The Theory and Practice of Self-Conscious Fiction. London: Routledge (Kindle Edition).

\title{
Возвращение субъекта
}

в немецком метаромане 1960-1990 гг.

\author{
В.В. Котелевская \\ Южный федеральньй университет \\ Россия, 344006, Ростов-на-Дону, \\ ул. Большая Садовая, 105/42
}

В статье рассматривается проект «смерти субъекта» на материале немеикоязычного метаромана 1960-1990 г2. Данный романный субжанр трактуется как наиболее адекватная литературная форма проблематизации модернистского субъекта. Героем метаромана чаще всего выступает художник или интеллектуал. Повествование вытесняется саморефлексией субъекта письма. Самосознание героя служит центром авторского внимания, поэтому метароман часто принимает форму саморефлексивного повествования - дневника, заметок, потока сознания. Анализируется творчество Томаса Бернхарда, объектом «пристального прочтения» является его роман «Корректура» (1975). На примере романа «Корректура» анализируются такие свойства метаромана, как амбивалентность «я» и Другого, проблематизация письма, 
трактовка искусства как жизни и жизни как искусства. Доказывается, что немецкоязычный метароман сохраняет свою связь с модернизмом и не утрачивает семантической «глубины», катарсиса, а также романтического представления о художнике как «гении».

Ключевые слова: литература модернизма, постмодерн, постструктурализм, немецкая литература, метароман, смерть субъекта, смерть автора, Томас Бернхард.

Научная специальность: 10.00.00 - филологические науки. 
